\title{
Influence of Family Structure and Functionality on Immunization Status of Infants Attending GOPC of BMC Saki
}

\author{
*Bolaji A.I ${ }^{1}$, Ojebode T.O², Adekanye O.S ${ }^{2}$, Bolaji A.O ${ }^{3}$
}

\begin{abstract}
Introduction: Vaccine-preventable diseases are endemic in Nigeria, and contribute greatly to childhood morbidities and mortalities. Good family structure has been reported to improve children's wellbeing, health and eating habit, but the contribution of family structure together with family functionality on immunization status has not been documented. Overall, the goal of the research was to determine the level of immunization status in the study population, assess their knowledge of immunization and determine what influence family structure and functionality have on children's immunization status.
\end{abstract}

Methods: A cross-sectional descriptive study was conducted in 2016 in the General outpatient clinic (GOPC) of Baptist Medical Centre (BMC), Saki, Oyo State. Family APGAR Scale and self-design questionnaire were used to collect data from 299 respondents using systematic sampling technique. A SPSS (version 21) was used for the analysis.

Results: Our results showed that $82.9 \%$ of the respondents were fully immunized and $98 \%$ had knowledge about Immunization. Majority of the respondents came from functional families, accounting for $85.6 \%$ of cases. The following factors were found to be statistically significantly associated with immunization status: family functionality $(X 2=101.694, P=0.000)$, family type ( $\mathrm{p}$ value $=0.000)$, family size ( $\mathrm{p}$ value $=0.000)$, ethnic group $(\mathrm{p}$ value $=0.000)$ and number of children $(\mathrm{P}$ value $=0.000)$

Conclusion: Our findings showed that there is an adequate knowledge of immunization in the study population, and that a child's immunization status is significantly influenced by the family structure and functionality. However, given the fact that this is a single, hospital-based study, several multi-center studies would have to be employed not just to validate this conclusion but also to inform policy making.

Keywords: Immunization status, family structure, family functionality, vaccine, health facility, Nigeria

\author{
*Corresponding Author \\ Bolaji A.I \\ http://orcid.org/0000-0003-2064-5570 \\ E-mail: adetola.bolaji@bowen.edu.ng
}

${ }^{1}$ Directorate of Health Services, Bowen University, Iwo.

${ }^{2}$ Department of Family Medicine, Baptist Medical Center Saki.

${ }^{3}$ Eleta Eye Institute, Ibadan. 


\title{
Influence de la structure familiale et de la fonctionnalité sur le statut de vaccination des nourrissons assistant au GOPC de BMC, Saki
}

\author{
*Bolaji A.I ${ }^{1}$, Ojebode T.O², Adekanye O.S ${ }^{2}$, Bolaji A.O ${ }^{3}$
}

\section{Introduction}

Les morts évitables par la vaccination restent endémiques et contribuent de manière significative à la morbidité infantile au Nigéria et il a été reconnu qu'une bonne structure familiale améliore le bien-être, la santé et les habitudes alimentaires des enfants, mais la contribution de la structure et de la fonctionnalité de la famille au statut vaccinal n'est pas encore établie. Le but de cette étude est de déterminer le niveau d'immunisation des répondants, d'évaluer leurs connaissances en matière d'immunisation et de déterminer l'influence de la structure et de la fonctionnalité de la famille sur l'état de vaccination.

Méthode de l'étude: Une étude descriptive transversale a été menée en 2016 dans la clinique externe générale (GOPC) du Baptist Medical Center (BMC), Saki, dans l'état d'Oyo. L'échelle familiale APGAR et le questionnaire d'auto-conception ont été employés pour recueillir des données auprès de 299 répondants à l'aide d'une technique d'échantillonnage systématique. Un SPSS (version 21) a été utilisé pour l'analyse.

Résultats de l'étude: Les résultats ont révélé que la majorité $(82,9 \%)$ des répondants était entièrement immunisée et que $98 \%$ avaient des connaissances sur la vaccination. La majorité des répondants $(85,6 \%)$ étaient issus de familles fonctionnelles. La fonctionnalité de la famille était statistiquement significative sur le statut vaccinal $(X 2=101,694, P=0,000)$ ainsi que sur certaines composantes de la structure familiale: type de famille $(\mathrm{P}=0,000)$, taille de la famille $(\mathrm{P}=0,000)$, groupe ethnique $(\mathrm{P}=0,000)$, et nombre d'enfants $(\mathrm{P}=0,000)$

Conclusion: Les répondants avaient une connaissance adéquate de la vaccination. De plus, la fonctionnalité familiale et la structure familiale influencent le statut vaccinal des nourrissons. Par conséquent, d'autres études devraient être menées sur l'influence de la fonctionnalité et de la structure de la famille sur le statut vaccinal en utilisant une approche multicentrique.

Mots-clés: Immunisation, fonctionnalité familiale, structure familiale, vaccine

\author{
*Corresponding Author \\ Bolaji A.I. \\ http://orcid.org/0000-0003-2064-5570 \\ E-mail: adetola.bolaji@bowen.edu.ng
}

${ }^{1}$ Directorate of Health Services, Bowen University, Iwo.

${ }^{2}$ Department of Family Medicine, Baptist Medical Center Saki.

${ }^{3}$ Eleta Eye Institute, Ibadan. 


\section{INTRODUCTION}

Immunization remains an important cost-saving, preventive strategy in the fight against infectious diseases globally (1). To combat these infectious agents, vaccines can be administered to stimulate immune responses, leading to antibodies production (2). It is saddening however to note that a vast majority of children who are at risk of contracting and dying from these illnesses do not have access to these life-saving preparations. ${ }^{3}$ Nigeria has one of the highest under-five mortality rates in the world, accounting for about 194 per thousand, out of which vaccine preventable diseases account for nothing less than $20 \%$ ! It is worrisome to note that even some countries that are going through conflicts have better immunization coverage than Nigeria $(5,6)$.

With respect to family structure, research studies have shown that nuclear family set ups have worse childhood immunization history compared to other household structures $(7,8)$. Moreover, whereas a number of studies reported the determinants of immunization uptake for example among children aged 12-23 months, studies among infants (aged 0-11 months) will determine this earlier.

Broadly, the family connotes any group of persons who are related biologically, emotionally or legally (9). It is logical therefore to assert that the family is the most important source of health beliefs and health-related behaviors, stress and emotional support. Family structure however, denotes its composition and membership, and remains the fundamental building block of social structure around the world (10).

According to $\mathrm{WHO}$, immunization is a process of protecting an individual against infectious diseases through an administration of vaccines (11). No doubt, immunization is one of the most useful and safest interventions in public health. It is estimated that 3 million lives can be saved by vaccination as it prevents diseases (10). Studies have shown that the number of parents in the household equally plays a very significant role in a child's physical growth and development (12).

Family functioning is a terminology that is used to describe the social as well as the structural attributes of a family as part of the global community. It relates to interactions that exist within a family setting, including but not limited to the ability to resolve conflicts, adapt, organize and effectively communicate. To determine the levels of family functioning, a 5-item questionnaire, popularly called family APGAR (Adaptation, Partnership, Growth, Affection and Resolve) scale, is often utilized (13). The scale can be used to categorize families based on their functionalities. The scale has 5 questions (with 3 possible answers - 0 for 'hardly ever', 1 for 'sometimes' and 2 for 'always', with the total score ranging from $0-10$ ), and measures the level of an individual's satisfaction with family relationships. On a scale of 10, a score of 7 (or higher) is indicative of a highly functional family, 4 to 6 , a moderately dysfunctional family and 3 and below, a severely dysfunctional family setting (14). A study on the influence of family structure and functionality on the immunization status of infants, in a primary care setting is therefore necessary, as it will put emphasis on the importance of immunization in child's health.

\section{MATERIALAND METHODS}

The study was a cross-sectional study using hospitalbased data collection to evaluate the association between family structure and functionality and immunization status of infants attending GOPC of Baptist Medical Centre, Saki (BMCS), specifically at the Infant welfare/postnatal clinic of the hospital. BMCS is one of the Nigerian Baptist Convention mission health facilities and is located in Saki, Saki West Local Government area of Oyo State. This 200bedded health institution was founded in May 1902 with the sole of purpose of providing both primary and secondary healthcare to the residents of OkeOgun and their neighboring communities, with referrals from other parts of Nigeria. The research was carried out among infants, aged 0-11 months, and their caregivers who attended the outpatient department of the health facility between May and October, 2016, who met both the inclusion and exclusion criteria and who consented to participate in the research. Additionally, the Fisher's statistical formula for estimating minimum sample size for single proportion in population of greater than 10,0000 was used to determine the sample size for the study $\left(N=Z^{2} \times P(1-p) / d^{2}\right)(15)$, where $N$ represents the minimum sample size for a statistically significant survey, $Z$, the normal deviant at $95 \%$ confidence interval (standard value being 1.96), $\mathrm{P}$ is the estimated immunization prevalence in the study area (approximately 23\% in Nigeria) (16) and d, the error margin at a standard value of $0.05(5 \%)$ minus precision. 
The sample size was therefore calculated thus:

$$
\begin{aligned}
\mathrm{N} & =\frac{1.962 \times 0.23(1-0.23)}{0.05^{2}} \\
& =272
\end{aligned}
$$

To accommodate contingencies like nonresponse or errors associated with recording, we increased the sample size by $10 \%$, giving a sample size of 299. Research subjects were recruited using a systematic random sampling technique. The outpatient clinic is run 5 days a week, with an approximately 12 infants attending each day, translating into about 60 infants per week, 240 every month and 960 over the 4-month period the study lasted. The required sample size for the study was arrived at by systematically selecting every $3^{\text {rd }}$ infant beginning with the $3^{\text {rd }}$ infant that attended the clinic at the start of the study. The $1^{\text {st }}$ to be recruited was selected using a simple random sampling namely balloting. This way, the $1^{\text {st }}$ study participant to be included was the $3^{\text {rd }}$ infant, the $2^{\text {nd }}$ was the $6^{\text {th }}$ infant, the $3^{\text {rd }}$ was the $9^{\text {th }}$ infant and so on, until the desired sample size was reached. In a situation in which the selected infant did not meet the inclusion criteria, we chose the next subject, while the sampling interval continued from that point. To avoid registering a child twice, we opened a register for all the infants that participated in the study, while we marked their cards. On the average, about 3 to 4 infants were recruited per day, and the exercise lasted for approximately 4 calendar months.

Our inclusion criteria were as follows: children aged 0-11 months, who were being seen at the general outpatient clinic of the hospital, and whose parents or caregivers were willing to participate in the study. Our exclusion criteria included infants with contraindication (e.g. on medical grounds) for immunization or whose parents or caregivers declined to participate. The lead researcher identified the children that met the aforementioned inclusion criteria, and also administered the questionnaires on their parents or caregivers. Each child's Road-toHealth Chart was critically examined by paying special attention to what immunization has or has not been received. Parents or caregivers who did not come with their children's charts were given an appointment to bring them the next visit for confirmation.

All the measurements were documented in the questionnaire which was pre-tested in the General Hospital Saki by the researcher. Family structure was classified into single parent, nuclear and non-nuclear families or multiple families (17). An infant was taken as any child aged 0 to 11 months (18). Data collection using structured questionnaires, validation of instruments and random auditing were done on a daily basis by the researcher.

Ethical approval was obtained before the commencement of the study from the Ethics Committee of the Hospital. Well written informed consent was obtained from each participant after adequate information had been given about what the study entailed to the parents and caregivers and after having assured them that their responses would be kept anonymous and treated with utmost confidentiality. All financial implications were borne by the authors, and there was no conflict of interest. Data were promptly entered into the questionnaires, transferred and stored into the lead author's personal computer using the Microsoft Excel Worksheet version 2007. Data were then exported and analyzed using the Statistical Package for Social Sciences (SPSS) version 21 for windows. Statistical significance was set at a confident interval of $95 \%$ and a P-value of $<0.05$. Fisher exact test was used to determine whether or not there was a significant association between the participants' family structure, family functionality and their immunization status. Any child in need of immunization during the study will have his/her caregiver adequately counseled before such services are given in the health facility.

\section{RESULTS}

\section{Characteristics of the Study Population}

Table 1 showed the socio-demographic features of the infants that were recruited for the study. The vast majority of the caregivers (representing 93.6\%), were biological mothers of the infants. Gender distribution revealed that 166 , accounting for $55.5 \%$, were male while $133(44.5 \%)$ were female. Infants aged 0-3 months accounted for more than half $(55.5 \%)$ of the participants. Majority of the caregivers $(61.5 \%)$ were Muslims, while about $74.2 \%$ of the caregivers resided in peri-urban settlements. Table 2 gives information about the socio-economic characteristics and anthropometric measurements of study participants. While about $222(74.2 \%)$ of the caregivers indicated trading as their occupation, only $17(5.7 \%)$ had post-tertiary education. Family income of more than $\$ 200,000$ was reported only by 16 of the caregivers, representing just $5.4 \%$ !

Table 3 depicts the family structure of the 
Table 1: Socio-demographic characteristics of the subjects $(n=299)$

\begin{tabular}{|c|c|c|}
\hline Variable & frequency $(f)$ & percentage $(\%)$ \\
\hline \multicolumn{3}{|c|}{ Informant relationship to the child } \\
\hline Father & 19 & 6.4 \\
\hline Mother & 280 & 93.6 \\
\hline Siblings & 0 & 0 \\
\hline \multicolumn{3}{|c|}{ Sex of the child } \\
\hline Male & 166 & 55.5 \\
\hline Female & 133 & 44.5 \\
\hline \multicolumn{3}{|c|}{ Age of the child (Months) } \\
\hline $0-3$ & 169 & 56.5 \\
\hline $4-6$ & 35 & 11.7 \\
\hline $7-9$ & 46 & 15.4 \\
\hline $10-11$ & 49 & 16.4 \\
\hline \multicolumn{3}{|c|}{ Number of Under 5 siblings in the family } \\
\hline None & 108 & 36.1 \\
\hline One & 109 & 36.5 \\
\hline 2 or more & 82 & 27.4 \\
\hline \multicolumn{3}{|c|}{ Religion of parent/caregiver } \\
\hline Christianity & 115 & 38.5 \\
\hline Islam & 184 & 61.5 \\
\hline Traditional & 0 & 0 \\
\hline \multicolumn{3}{|l|}{ Residence } \\
\hline Urban & 22 & 7.4 \\
\hline Peri-urban & 222 & 74.2 \\
\hline Rural & 55 & 18.4 \\
\hline
\end{tabular}

participants. Approximately three quarters (78.9\%) of the children came from a 2-parent family setting with the least of their family size being 2 . Approximately $260(88.3 \%)$ of the infants had caregivers who were currently married, $3 \%$ were Igbo, family expenses were mainly borne by the fathers, accounting for about $90.6 \%$ while approximately $94.3 \%$ of the household heads were male.Figure 1 shows the family functionality of the infants. Majority of the participants $(85.6 \%)$ hailed from functional family setting.

Figure 2 gives a summary of the number of respondents who had been fully immunized. Two hundred and forty-eight of the participants, accounting for $82.9 \%$, have received full immunization appropriate for their ages.

Table 4 summarizes the level of knowledge of immunization among the caregivers. While most (about 98\%) have had some knowledge of immunization, just about $91 \%$ of these could be said to truly understand the purpose of immunization.

Table 5 is a summary of the association that existed between the family functionality and the participants' immunization standing. A very strong relationship was observed between the infants' immunization status and their family functionality $\left(X^{2}=101.694, p\right.$ value $\left.=<0.001 ; d f=2\right)$. Infants with 'nil immunization status' accounted for $34.9 \%$, and all of them came from dysfunctional families. Greater proportion $(89.5 \%)$ of those with full immunization status came from functional family setting.

Table 6 shows the relationship between the family structure and the infant's immunization status. The participants' immunization status was significantly associated with their family type (Fisher $=29.988, \mathrm{p}$ value $=0.000, \mathrm{df}=4)$. All the children (100\%) from single-parent family set up had been fully immunized, about $86(89.6 \%)$ of the participants with full immunization status had family size of $3\left(\mathrm{X}^{2}=37.309, \mathrm{p}\right.$ value $\left.=0.000, \mathrm{df}=8\right)$. A vast majority $(84.6 \%)$ of the respondents, who were of Yoruba extraction, had been fully immunized. It is also clear from the table that family type with 3 children constituted the majority of those who have been fully immunization $\left(\mathrm{X}^{2}=53.279, \mathrm{p}\right.$ value $=$ $0.000, \mathrm{df}=8$ ) 
Table 2: Socio-economic characteristics of the subjects' parent/caregiver $(\mathrm{n}=299)$

\begin{tabular}{|c|c|c|}
\hline Variable & frequency $(f)$ & percentage $(\%)$ \\
\hline \multicolumn{3}{|c|}{ Occupation of parent/caregiver } \\
\hline Civil servant & 44 & 14.7 \\
\hline Trading & 222 & 74.2 \\
\hline Farming & 6 & 2.0 \\
\hline Others & 27 & 9.1 \\
\hline \multicolumn{3}{|c|}{ Highest level of education of the caregiver } \\
\hline None & 28 & 9.4 \\
\hline Primary & 58 & 19.4 \\
\hline Secondary & 107 & 35.7 \\
\hline Tertiary & 89 & 29.8 \\
\hline Post- tertiary & 17 & 5.7 \\
\hline \multicolumn{3}{|c|}{ The child caregiver relationship } \\
\hline Parents & 296 & 99 \\
\hline Parents-in-law & 3 & 1 \\
\hline Others & 0 & 0 \\
\hline \multicolumn{3}{|c|}{ Father's level of education } \\
\hline None & 10 & 3.3 \\
\hline Primary & 21 & 7.0 \\
\hline Secondary & 120 & 40.2 \\
\hline Tertiary & 110 & 36.8 \\
\hline Post-tertiary & 38 & 12.7 \\
\hline \multicolumn{3}{|c|}{ Family income in a month } \\
\hline Less 25,000 & 45 & 15.0 \\
\hline $25,000-50,000$ & 159 & 53.2 \\
\hline $51,000-100,000$ & 64 & 21.4 \\
\hline $101,000-200,000$ & 15 & 5.0 \\
\hline More than 200,000 & 16 & 5.4 \\
\hline \multicolumn{3}{|l|}{ Birth order of child } \\
\hline First & 92 & 30.8 \\
\hline Second & 63 & 21.1 \\
\hline Third & 76 & 25.4 \\
\hline Fourth & 56 & 18.7 \\
\hline Fourth and above & 12 & 4.0 \\
\hline
\end{tabular}

*Others included unemployed, housewives, tailoring and knitting

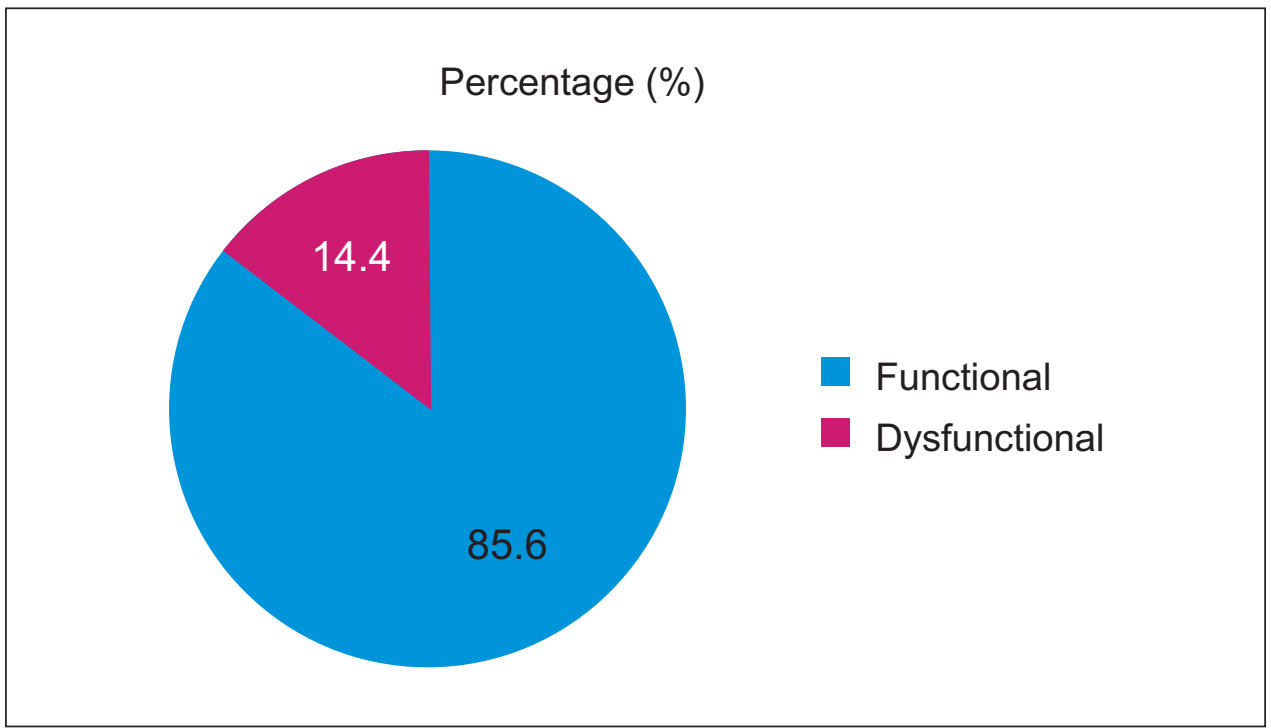

Figure 1: Functionality of the families of the subjects 
Table 3: Household structure of the subjects

\begin{tabular}{|c|c|c|}
\hline Variable & frequency (f) & percentage $(\%)$ \\
\hline \multicolumn{3}{|l|}{ Family type } \\
\hline Single parents & 19 & 6.4 \\
\hline Two parents & 236 & 78.9 \\
\hline Extended & 44 & 14.7 \\
\hline \multicolumn{3}{|l|}{ Family size } \\
\hline Two & 3 & 1.0 \\
\hline Three & 96 & 32.2 \\
\hline Four & 68 & 22.7 \\
\hline Five & 58 & 19.4 \\
\hline$>$ Five & 74 & 24.7 \\
\hline \multicolumn{3}{|c|}{ Marital status of the caregiver } \\
\hline Single & 27 & 9.0 \\
\hline Married & 264 & 88.3 \\
\hline Divorced & 8 & 2.7 \\
\hline Separated & 0 & 0 \\
\hline Others & 0 & 0 \\
\hline \multicolumn{3}{|l|}{ Ethnic group } \\
\hline Yoruba & 272 & 91.0 \\
\hline Hausa/Fulani & 18 & 6.0 \\
\hline Igbo & 9 & 3.0 \\
\hline Others & 0 & 0 \\
\hline \multicolumn{3}{|c|}{ Family expenses bearer } \\
\hline Father & 271 & 90.6 \\
\hline Mother & 3 & 1.0 \\
\hline Others & 25 & 8.4 \\
\hline \multicolumn{3}{|l|}{ No of children } \\
\hline 1 & 109 & 36.5 \\
\hline 2 & 53 & 17.7 \\
\hline 3 & 66 & 22.0 \\
\hline 4 & 40 & 13.4 \\
\hline$>5$ & 31 & 10.4 \\
\hline \multicolumn{3}{|c|}{ Sex of household head } \\
\hline Male & 282 & 94.3 \\
\hline Female & 17 & 5.7 \\
\hline Total & 299 & 100 \\
\hline
\end{tabular}

Table 4: Knowledge of immunization of the caregivers

\begin{tabular}{llllll}
\hline Immunization & \multicolumn{2}{c}{ Heard } & \multicolumn{3}{c}{ Not heard } \\
& F & $\mathbf{0}$ & F & \% \\
\cline { 2 - 6 } & 293 & 98.0 & 6 & 2.0 \\
\cline { 2 - 6 } & \multicolumn{2}{c}{ Yes } & \multicolumn{3}{c}{ No } \\
\cline { 2 - 6 } Immunization is the protection from some diseases & 272 & 91.0 & 27 & 9.0 \\
Immunization is a birth control method & 24 & 8.0 & 275 & 92.0 \\
Immunization of treatment for infection & 51 & 17.1 & 248 & 82.9 \\
\hline
\end{tabular}

Table 5: Family functionality and Immunization Status

\begin{tabular}{lccccccc}
\hline Variable & \multicolumn{9}{c}{ Immunization Status } & \multirow{2}{*}{ Fi } & P-Value & df \\
\cline { 2 - 6 } & None & Any & Full & Total & & & \\
& $(\mathbf{1 5 )}$ & $\mathbf{( 3 6 )}$ & $\mathbf{( 2 4 8 )}$ & $\mathbf{( 2 9 9 )}$ & & & \\
& $\mathrm{n}(\%)$ & $\mathrm{n}(\%)$ & $\mathrm{n}(\%)$ & $\mathrm{n}(\%)$ & & & \\
\hline Dysfunctional & $15(34.9)$ & $9(20.9)$ & $19(244)$ & $43(100)$ & 101.694 & $<0.001$ & 2 \\
Functional & $0(0)$ & $27(10.5)$ & $229(89.5)$ & $256(100)$ & & & \\
\hline
\end{tabular}


Table 6: Association between family structure and immunization status

\begin{tabular}{|c|c|c|c|c|c|c|c|}
\hline \multirow[t]{2}{*}{ Variable } & \multicolumn{4}{|c|}{ Immunization status } & \multirow[b]{2}{*}{$\mathbf{F i}$} & \multirow[b]{2}{*}{ P-value } & \multirow[b]{2}{*}{ Df } \\
\hline & None & Any & Full & Total & & & \\
\hline & $(15)$ & (36) & $(248)$ & 299 & & & \\
\hline & $\mathrm{N}(\%)$ & $\mathrm{N}(\%)$ & $\mathrm{N}(\%)$ & $\mathrm{N}(\%)$ & & & \\
\hline \multicolumn{8}{|l|}{ Family type } \\
\hline Single Parent & $0(0)$ & $0(0)$ & $19(100)$ & $19(100)$ & & & \\
\hline Nuclear & $6(2.5)$ & $33(14)$ & $197(83.5)$ & $236(100)$ & 29.988 & $<0.001$ & 4 \\
\hline Nuclear Extended & $9(20.5)$ & $3(6.8)$ & $32(72.7)$ & $44(100)$ & & & \\
\hline \multicolumn{8}{|l|}{ Family size } \\
\hline Two & $0(0)$ & $0(0)$ & $3(100)$ & $3(100)$ & & & \\
\hline Three & $0(0)$ & $10(10.4)$ & $86(89.6)$ & $96(100)$ & & & \\
\hline Four & $0(0)$ & $9(13.2)$ & $59(86.8)$ & $68(100)$ & 54.722 & $<0.001$ & 8 \\
\hline Five & $0(0)$ & $4(6.9)$ & $54(93.1)$ & $58(100)$ & & & \\
\hline$>$ five & $15(20.3)$ & $13(17.6)$ & $46(62.2)$ & $74(100)$ & & & \\
\hline \multicolumn{8}{|l|}{ Marital status } \\
\hline Single & $0(0)$ & $0(0)$ & $27(100)$ & $27(100)$ & & & \\
\hline Married & $15(15.7)$ & $36(13.6)$ & $213(80.7)$ & $264(100)$ & 8.152 & 0.086 & 4 \\
\hline Divorced/separated & $0(0)$ & $0(0)$ & $8(100)$ & $8(100)$ & & & \\
\hline \multicolumn{8}{|l|}{ Ethnic group } \\
\hline Yoruba & $9(3.3)$ & $33(12.1)$ & $230(84.6)$ & $272(100)$ & & & \\
\hline Hausa/Fulani & $6(33.3)$ & $0(0)$ & $12(66.7)$ & $18(100)$ & 37.309 & $<0.001$ & 4 \\
\hline Igbo & $0(0)$ & $3(33.3)$ & $6(66.7)$ & $9(100)$ & & & \\
\hline \multicolumn{8}{|c|}{ Family expenses bearer } \\
\hline Father & $15(15.5)$ & $36(13.3)$ & $220(81.2)$ & $271(100)$ & 6.353 & 0.174 & 4 \\
\hline Mother & $0(0)$ & $0(0)$ & $3(100)$ & $3(100)$ & & & \\
\hline Others & $0(0)$ & $0(0)$ & $25(100)$ & $25(100)$ & & & \\
\hline \multicolumn{8}{|l|}{ No of children } \\
\hline 1 & $1(0.9)$ & 13(11.9) & $95(87.2)$ & $109(100)$ & 53.279 & $<0.001$ & 8 \\
\hline 2 & $0(0)$ & $9(17)$ & $44(83)$ & $53(100)$ & & & \\
\hline 3 & $0(0)$ & $4(6.1)$ & $62(93.6)$ & $66(100)$ & & & \\
\hline 4 & $6(15)$ & $4(10)$ & $30(75)$ & $40(100)$ & & & \\
\hline \multicolumn{8}{|l|}{$\geq 5$} \\
\hline \multicolumn{8}{|c|}{$\overline{\text { Sex of household head }}$} \\
\hline Male & $15(5.3)$ & $36(12.8)$ & 231(81.9) & $282(100)$ & 3.707 & 0.157 & 2 \\
\hline Female & $0(0)$ & $0(0)$ & $17(100)$ & $17(100)$ & & & \\
\hline
\end{tabular}

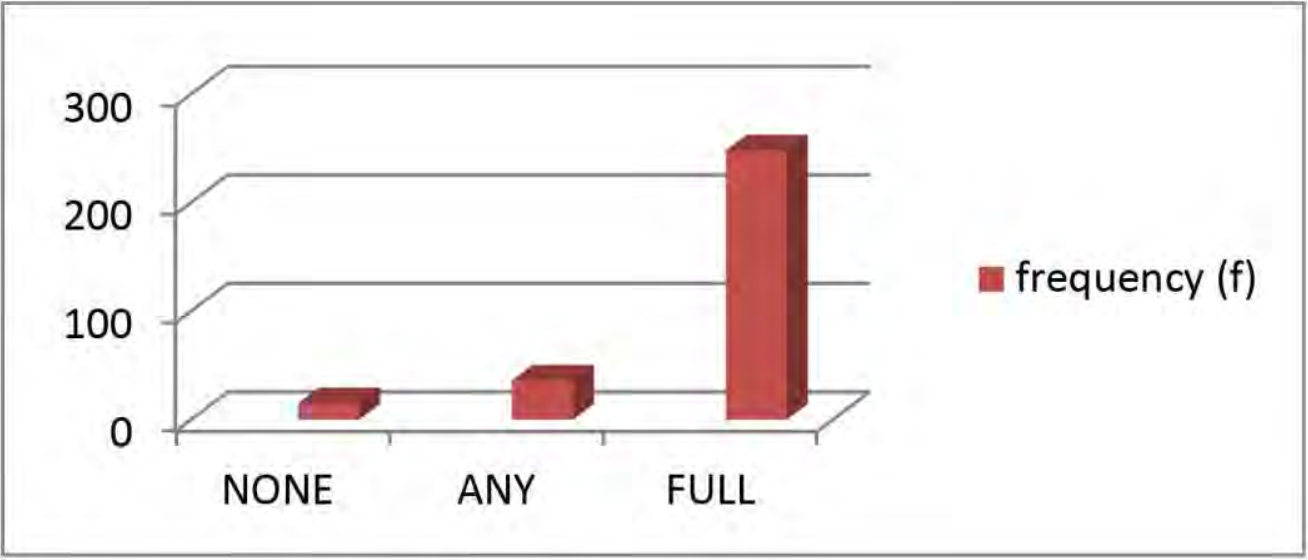

Figure 2: Immunization status/coverage of the subjects 


\section{DISCUSSION}

Our research showed that a greater percentage (78.9\%) of the study participants belonged to twoparent families. This finding is in agreement with previous studies conducted in Chatsworth, South Africa, Asia as well as in the Middle East where presence of both the father and the mother in a nuclear family setting was reported as the predominant household structure, as high as $63.8 \%$ (19). Several other studies conducted in some selected countries like Kenya, Nigeria, South Africa, India, Peru, Colombia and Nicaragua have however reported lower percentages, ranging from about $52 \%$ to $70 \%$ (20). This study also noted that most respondents reported the father as the head of the family, accounting for about $94.3 \%$ of cases. Similar finding had earlier been reported by Akinyemi among some selected communities in Africa (21). In this study, the proportion of children that were living in families headed by female ranged from about $5.2 \%$ in Burkina Faso to about $49.1 \%$ in Namibia. This is not surprising because while there are documented evidences of increasing numbers of mothers, grandparents, and children heading the family (22), in African culture generally, this role is performed mainly by the fathers. That children are now taking up the responsibility of heading the family in some settings in Africa may not be unconnected with the fact that HIV-AIDS is taking its tolls on the family by reducing the lifespan of most parents. The study equally noted that a high proportion of the participants $(85.6 \%)$ had history suggestive of living in families that are functional. Again, this agrees with the study of Muyibi and others (23) in which about $84.5 \%$ of their respondents in Ibadan, Southwest Nigeria, were reported to come from functional families. Further, there are documented evidences of similar findings in Spain, namely $79.35 \%$ and $84 \%$ by Rodriguez et al and Bellon et al respectively (24, 25 ). It can be safely concluded therefore that sociocultural differences and economic disparities that exist between the developed and less developed economies of the world have little or no influence on the family functionality, in fact, reports have it that dysfunctional families have no social, financial or intellectual boundaries (26). The level of family functionality in our study is, however, higher compared to what was reported in Anambra State, Southeast Nigeria $(27,28)$. The reason may be due to the difference in ethnicity between the people in the Southwest and those in the Southeast of Nigeria, however, further research would be needed to substantiate this. The percentage of infants that were immunized for age in this study was high (82\%). This was higher than that of a peri-urban study in Kenya, Pakistan and India which reported coverage of $76.6 \%, 44.8 \%$ and $44 \%$ respectively $(18,29,30)$. It was also more when compared with the National average (23\%), as well as $8.3 \%, 1.6 \%, 1.5 \%$ and $1 \%$ from Kastina, Zamfara, Yobe and Jigawa states respectively from Northern Nigeria $(16,31,32)$. However, studies from Americas, Europe and Western Pacific reported immunization coverage above $90 \%$. The widespread information and worldwide awareness about immunization including National immunization days, as well as Mop-up programmes might be responsible for the high coverage seen in this study. Moreover, immunization knowledge level among the caregivers was found to be high (98\%). Interestingly, similar finding was reported in a study done in Igbo-ora, Oyo state, Southwestern Nigeria where the knowledge level was $99 \%$. However, studies conducted in United Arab Emirates and Saudi Arabia reported lower level of knowledge ( $85 \%$ and $91.9 \%$ ) respectively when compared to our finding.

This study found that a significant relationship exists between functionality of the children's families and their immunization status. $89.5 \%$ of fully immunized children were from functional families while dysfunctional families contributed all nonimmunized children $(p<0.05)$. Studies by Vandermeulin et al and Adeyinka et al supported this finding when they reported that cooperation between parents as well as Family/cultural support influence full childhood immunization status of chidren. ${ }^{36,37}$ The strong relationship seen in this study is not unexpected because functional families usually demonstrates good attitude towards live since all the members strife and cooperate towards the welfare of all family members. ${ }^{38,39}$ In fact, Children development, education, health and well-being is greatly influenced by family functioning and parenting practices (40).

This Study revealed that immunization status of the children was significantly influenced by some family structure components. For instance, all $(100 \%)$ subjects from single parent family were fully immunized for age when compared to children from two-parent and extended families. Similar report was made in a study done in Dschang, Cameroun where children from single parent families were found to have higher coverage of immunization (41). This may 
not be surprising because attention of a single parent is not likely to be taken away from his/her child when compared with both parent families.

A similar finding was reported by an Indian study which found that children of non-nuclear families were found to be at greater advantage in terms of immunization (42). However, a study done in a rural area of Oyo State, Southwestern Nigeria is in contrast to our study by reporting that children from monogamous families were two times more likely to complete their doses of immunization when compared to their polygamous counterpart (43).

Moreover, our study revealed strong relationship between family size and immunization status such that all the $3(100 \%)$ who had full immunization status came from family size not greater than two. This finding was supported by a study done in Owerri, Nigeria where higher odds of full childhood immunization status was found in mothers whose family size was less than three when compared with those with family size more than six (44). The finding in our study did not come by surprise since families consisting of the caregiver and only one child is likely to concentrate on the health of the child with little distractions.

\section{CONCLUSION}

The study was done to find out the association between family functionality and family structure, and immunization status of infants seen at the GOPC of a mission hospital. Our study was able to establish that the coverage of immunization among the respondents was high $(82.9 \%)$. A high level of immunization knowledge was also found in this study with (98\%) of the respondents having adequate knowledge about immunization. Majority (85.6\%) were from functional families. Moreover, the association between family functionality and immunization status of the respondent was found to be significant statistically. Also, association between family size, family type and number of children in the family, and children immunization status was statistically significant.

In the light of these findings, Physicians are advised to always dig into the structure and functionality of families of all children within the ages of immunization as this information this will enhance the coverage of immunization.

\section{LIMITATION}

The sample population in this study is limited to infants who attended GOPC of Baptist Medical Centre, Saki. It did not reveal information about other children in the community who were not seen in the clinic.

\section{CONFLICT OF INTEREST}

The authors have not declared any conflict of interests.

\section{REFERENCES}

1. Ali M, Sur D, Lopez AL, Kanungo S, Ochiai RL, Manna B, et. al. Community Participation in Two Vaccination Trials in Slums of Kolkata, India: A Multi-level Analysis. HealthPopulNutr 2010; 28(5): 450-457.

2. Saroja CH, Lakshmi PK, Bhaskaran S. Recent trends in vaccine delivery system: A Review. Int J Pharm Investing 2011; 1(2):64-74.

3. Molina AC, Godoy I, Carvalho LR, Caldas AL. Infant vaccination situation and individual and family characteristics of the interior of São Paulo. Acta Sci. Health Sci. 2007; 29(2):99-106.

4. FBA Health System Analysts. The state of Routine Immunization Services in Nigeria and Revisions for Current Problems. Abuja, Nigeria: DFID, 2005.

5. Folliden B. Health System Analysts. The State of Routine Immunization Services in Nigeria and Reasons for Current Problems. June 2005;8: 3-42.

6. Jorgensen A, Padersea TP, Meilstrup CR. The influence of family structure on breakfast habit among adolescents: Dan Med Bull. 2011; 58(5):4262.

7. Gage AJ, Sommerfelt E, Piani A. Household structure and childhood immunization in Niger and Nigeria. Demography 1997; 34(2):295-309.

8. Babalola S. Adewuyi A. Factors Influencing Immunization Uptake in Nigeria: A Theory-based Reseach in Six States. Abuja: PATHS; 2005.

9. Pequegnat W, Bray JH. Families and HIV/AIDS J from psych 11:3, 1997. In: The Family's Influence on Health.CambellTL,Bray JH. Rackel RE. Textbook of Family Practice, $6^{\text {th }}$ ed.2002: $p ; 31$.

10. Emaj U. Cross-Cultural family structure between Muslim and Santal communities in Bangladesh: A Review:Antrocom. 2010; 6(1): 7-12. 
11. Williams KS, Sassler A, Frech F. Addo, Cooksey E. "Policy Brief." journal of Health and Social Behaviour. 2013; 54:277.

12. Boundless. "Family Structures." Boundless Sociology Boundless, 08 Aug. 2016. Retrieved 09 Jan. 2017 from https://www.boundless .com/sociology-textbook/family-12/family91/family-structures-521-10352/.

13. Paraszki RD, Walsh D. Family distress in palliative medicine: A pilot study of Family APGAR Scale. Amer J hops Palliative care. 2002; 19(6):292-396.

14. Sousa F, Figueiredo M, Erdmann A. Instruments for assessment and family intervention: A descriptive study.2010; 11(1):160-163.

15. Ibrahim T. Research Methodology and Dissertation writing for Health and Allied Health Professional Nigeria: Cress Globat link limited. 2009:70-75.

16. National pop Commission. Nigeria and ORL macro nutrition status of children. Nigeria Demographic and Health Survey (NDHS). Maryland: National Population Commission, Nigeria Macro;2008.163168.

17. Ferrer RL, Burge PR. The family Contribution to health status: A population level estimate. Ann Fam Med. 2005;3(2):102-108.

18. Lawan UM, Amole GT, Wali NY, Jahun MG, Jibo AM, Nakore AA. Pattern of adverse events following immunization in nourished and malnourished infants in Kano, North-Western Nigeria. Sahel Med J 2016; 19:131-136.

19. Kumar A, Ram F. Influence of Family Structure on Child Health: Evidence from India. Journal of Biosocial Science.2013; 45: 577-599.

20. Mapping family change. Two, one, or no parents? Children's Living Arrangements and Educational Outcomes Around the World.An international report from child trends. World Family Map 2013. www.worldfamilymap. ifstudies.org/2013/eppendix/figure5.

21. Akinyemi JO, Chisumpa VH, Odimegwu CO. Household structure, maternal characteristics and childhood mortality in rural sub-Saharan Africa. Rural Remote Health. 2016 Apr-Jun;16(2):3737.

22. Sewpaul V, Pillay A. Household and family structure: a baseline study among primary school learners in Chatsworth, South Africa. Social Work/Maatskaplike Werk 2011; 47(3):288.

23. Muyibi AS, Ajayi I-OO, Irabor AE, Ladipo MMA. Relationship between adolescents' family function with socio-demographic characteristics and behavior risk factors in a primary care facility.Afr $\mathrm{J}$ Prm Health Care Fam Med. 2010; 2(1):177-182.

24. Rodriguez FE, Gea SA, Gomez MA, Garcia JM. Apgar questionnaire in the study of family function.Aten Primaria.1996; 17(5):338-341.

25. Bellón JA, Delgado SA, Luna JD,Lardelli CP. Validity and Reliability of family APGAR family function test.Aten Primaria.1996; 18(6):289-296.

26. Laura Z. A Family of Neglect and "Dysfunction" Personal Blames or Structural Constraints? Human architecture: Journal of the sociology of Selfknowledge.2007; 2:125-136.

27. Nwabunwanne CO. Families at crossroads: Whither the future of youths? Catholic Teachers' Newsletter .2010; 1(3): 2-6.

28. Nwokolo C.Family environmental variables and deviant behaviors among Secondary school students in Onitsha Education zone. Nigerian Journal of Teacher Education and Teaching (2007); 3 (1): 171-179.

29. Maina LC, Karanja S, Kombich J. Immunization coverage and its determinants among children aged 12 - 23 months in a peri-urban area of Kenya. The Pan African Medical Journal. 2013; 14:3. doi:10.11604/pamj. 2013.14.3.2181.

30. Siddiqi N, Khan A, Nisar N, Siddiqi A. Assessment of Expanded program of immunization (EPI) vaccine coverage in a peri-urban area. Journal of the Pakistan Medical Association - September 2007; 57(8):391-395.

31. National pop Commission. Nigeria and ORL macro nutrition status of children. Nigeria Demographic and Health Survey (NDHS). Maryland: National Population Commission, Nigeria Macro;2008.163168.

32. Odusanya OO, Alufohai EF, Meurice FP, Ahonkhai VI. Determinants of vaccination coverage in rural Nigeria. BMC Public Health.2008, 8:381.

33. Obiajunwa PO. Olaogun AA. Childhood Immunization Coverage in South West Nigeria.Sudanese Journal of Public Health, 2013; 8, 94-98.

34. Bernsen RM, Al-Zahmi FR, Al-Ali NA, Hamoudi RO, Ali NA, et al. Knowledge, attitude and practice towards immunizations among mothers in a traditional city in the United Arab Emirates. Journal of Medical Sciences.2011; 4: 114-121.

35. Yousif MA, Albarraq AA, Abdallah MAA, Elbur AI. Parents' Knowledge and Attitudes on Childhood Immunization, Taif, Saudi Arabia. J Vaccines Vaccin 
2013; 5:215. doi:10.4172/2157-7560.1000215.

36. Vandermeulen C, Roelants $M$, Theeten $H$. Vaccination coverage in 14-year-old adolescents: documentation, timeliness, and sociodemographic determinants. Pediatrics 2008; 121:428-434.

37. Adeyinka D, Oladimeji O, Adeyinka F, Aimakhu C. Uptake of Childhood Immunization Among Mothers of Under-Five in Southwestern Nigeria. The Internet Journal of Epidemiology. 2008; 7:2.

38. Kissane D, Bloch S. Family Focused Grief Therapy: a model of Family-centred care during palliative care and bereavement. Buckingham, Philadelphia: Open University Press;2002. In: Tan HM. The experience of palliative patients and their families of a family meeting utilized as an instrument for spiritual and psychosocial care. BMC Palliat Care. 2011; 10:7.

39. Krauss W. Measures of Stress and Coping in Families. In: H.B. Weiss and F.H. Jacobs, (eds.) Evaluating Family Programs. New York: Aldine de Gruyter; 1988. pp. 177-194.

40. Nelson SK, Kushlev K, Lyubomirsky S. The pains and pleasures of parenting: When, why, and how is parenthood associated with more or less well-being? Psychol. Bull. 2014; 140 846-895.

41. Russo G, Miglietta A, Pezzotti P, Biguioh RM, Mayaka GB, Sobze MS et al. Vaccine coverage and determinants of incomplete vaccination in children aged 12-23 months in Dschang, West Region, Cameroon: a cross-sectional survey during a polio outbreak BMC Public Health 2015; 15:630

42. Choi JY, Lee S. Does Prenatal Care Increase Access to Child Immunization Bias among Children in India? Social science \&Medicine.2006; 63(1):107117.

43. Adebayo BE, Oladokun RE, Akinbami FO. Immunization Coverage in A Rural Community in Southwestern Nigeria. J Vaccines Vaccine. 2012; 3:143. doi:10.4172/2157-7560.1000143.

44. Osuala UK. Predictors of Full Childhood Immunization Status in Owerri, Nigeria. Dissertation Submitted in Partial Fulfillment of the Requirements for the Degree of Doctor of Philosophy Public Health, Walden University. March, 2015. 